\title{
SPECIAL ISSUE: \\ THE JAPANESE BUSINESS SYSTEM
}

\section{The Development of the Organizational Structure of Top Management in Meiji Japan}

\author{
By Tsunehiko Yui \\ Meiji University \\ Translated by Stephen W. McCallion
}

When one compares the managerial structure of large Japanese firms with those in the advanced nations of the West, a number of important peculiarities and differences become apparent. In fact, as is well known, even among the Western industrial nations - England, the United States and Germany, for example - there are significant legal and institutional variations in this regard, variations which result from differing historical and socioeconomic conditions. But the structure of top management in Japan is completely at variance with managerial structures found in the West in the following three respects.

The first and most important of these is the fact that the torishimariyakukai (board of directors) does not control management of a firm, but rather is absorbed into top management itself. In other words, we do not see in Japan a process in which a board of directors, by virtue of owning or having invested in a firm, selects the actual managing executives of the enterprise; rather, the managing directors of the firm serve as the board of directors - i.e., it is they who have control of the business and who exercise management. A board of directors in a major Japanese company today differs from its Western counterpart in that it is also, in effect, a committee of top managing executives.

The second difference is the fact that within the hierarchical structure of top managment in Japan, rank order frequently has priority over functional role assignments. Whereas in countries like the United States a horizontal system of vice-presidents, each of whom has responsibility for one division of the firm, was established, in Japan there developed over time a hierarchical structure consisting of kaicho (chairman), shacho (president), senmu torishimariyaku (senior executive director), jomu torishimariyaku (executive director) and (hira) torishimariyaku (junior executive director). This does not, it should be noted, necessarily imply 
that among those with the position of each executive director there was no system of divisional responsibility. In addition to this structural difference, there was almost no development within top management in Japanese firms of the kinds of committees (executive committees, etc.) one sees in nations like the United States. ${ }^{1)}$

The. third difference is the fact that the vast majority of those who make up the top management of firms come from within their firm. Very few are outsiders, and those who are typically have a rather unimportant status within the managerial structure. The top management of firms in Japan is, in this respect, extremely exclusive.

Assuming that the managerial structure of Japanese firms is as described above, one can also say that these same characteristics are the basis for what is called "Japanese-style management." The basic structure for this kind of management was developed during the first half century of industrialization in Japan - largely, that is, during the Meiji period (1868-1912). Even the zaibatsu (large diversified industrial organizations based on the exclusive ownership of capital by one extended family), most of which did not incorporate the businesses they owned until after 1910, displayed the same characteristics and tendencies described above. It is the intent of the author, then, to examine how the top management of Japanese firms developed their characteristic structure from the latter half of the nineteenth century.

\section{Management in the Initial Period of Structural Instability}

The Meiji Restoration of 1868 was an epochal event that marked the end of feudalism in Japan and the beginning of economic modernization. In the years immediately after the Restoration, there were some who established businesses modeled after Western firms; few of them had much idea how to go about it. The first such businesses set up included Tsusho Kaisha (The Trading Company, established in 1869), Kawase Kaisha (The Exchange Company, established in 1869 in the major urban centers), Maruya Shosha (The Maruya Trading Company, established in 1869), and Rikuun Moto Kaisha (The General Transportation Company, established in 1872). Most of them did not last very long; nor is it clear that most of them ever attained legal status as business organizations independent of the original investors in the enterprise. Information on the organization of these early, short-lived companies is available, but we will not discuss them here. ${ }^{2)}$

Japan's first genuine modern businesses were banks, established as a result of the issuance in 1872 (some twenty years before the enactment of the commercial and civil codes) of the National Bank Ordinance, 
modeled after the American Federal Reserve system. It was through these banks that the Japanese were able to acquaint themselves with the organization and structure of joint-stock companies. Only four banks were set up as a result of the aforementioned ordinance; but an 1876 revision of the ordinance abolished the original cash reserve requirement of sixty percent of capital funds, and allowed the members of the former warrior (samurai) class to invest the commutation bonds they had received in banks. Thereafter, the number of national banks increased rapidly. Until 1876 , former samurai had been receiving stipends; in that year, the stipends were abolished and replaced with interest-bearing commutation bonds, the face value of which amounted to 174 million yen. The former samurai proceeded to invest this money in the national banks. Long-established merchants, landlords and aristocrats (i.e. former feudal lords) also took part in the establishment of these banks. In addition to banks, joint-stock companies were set up in the areas of rail transportation, insurance, trade, and in manufacturing industries. There was, in fact, a veritable boom in the establishment of businesses in Japan during the latter half of the 1870 s.

The top management of companies set up during this time - when the government was most directly involved in attempts to promote both the establishment of new industries and overall increases in productivity - were based on a structure topped by a "president" and "director". Many of the Japanese words used with regard to business were coined at this time, and it is useful to bear their meanings in mind. Kaisha (company) refers to a business organization set up by a group of people for a common purpose; kabushiki kaisha (joint-stock company), to a company which has the authority of its investors to sell stock; and shacho (president), to the company's representative and leader. The word torishimariyaku (director), which was not new, referred to a number of functions, including those of administrator and supervisor. . As we shall see, these words were to become the source of some organizational confusion. The very notion of a joint-stock company was an alien one to the Japanese, as was the business system it represented. Consequently, the functions of president and/or director were conceived according to the managerial activities of traditional mercantile families; and while this kind of managerial structure bore a superficial resemblance to its Western counterpart, from the beginning it differed from the Western board of directors model both practically and structurally.

The companies set up in the late 1870s were legal entities independent of their investors. The notion of a business as an independent corporate entity was one understood with relative ease at this time, since it had 
some traditional precedent: as commercial activity had expanded in the Tokugawa era (1.603-1867), it had not been uncommon for wealthier merchants to make some degree of distinction between the management of their enterprises and their household assets and expenditures. Likewise, the idea that the president of a company should function as both the company's highest authority and as its spokesman was understood, and in the vast majority of cases the president did indeed perform these functions. In the banking industry, the president was given the title todori, a traditional term connoting essentially the same meaning as shacho. Section 8 of the 1872 National Bank Ordinance stated that it was the duty of the todori "to concern (himself) with, and assume responsibility for, the entire activities of the bank"; the model articles of incorporation included in the revised ordinance of 1876 provided further that "the todori shall be selected from among the directors of the bank at a general meeting of these directors." 3 ) In both banking and non-banking businesses, it was the duty of the president to preside over meetings of the board of directors and over general stockholders' meetings.

Still to be adequately defined, however, were responsibilities, status and duties of the directors (torishimariyaku) of a business. The term torishimariyaku is itself ambiguous, a fact which made it all the more difficult to define precisely what role directors were to play. In most cases, directors assumed their position upon being selected solely on the basis of their being major investors in the enterprise (all companies required in their articles of incorporation that directors be, at the very least, stockholders). This was in keeping with traditional mercantile practice, where cooperative activity was involved and where similar qualifications were required. There were some instances where directors were chosen who were not themselves major stockholders; but even here, those chosen had been among the originators of the enterprise and had managed to raise a substantial amount of share capital for it. Such directors certainly considered themselves part of the company's top management, though rather than direct their efforts in a managerial capacity they exercised power in the company as stockholders, and represented the interests of stockholders as a whole. Most of them had little knowledge of, or talent for, the business in which they were involved; therefore, although they considered themselves in major positions within the company, in fact their managerial status was not at all clear, and they tended to have little say in the practical operations of the firm.

Let us consider some examples of the rights and responsibilities of these directors. We will consider articles of incorporation from various 
types of business and from various geographical regions.

Between 1876 and 1879, 150 banks were established in Japan in accordance with the National Bank Ordinance. The ordinance defined the rights and duties of a bank's directors as follows:

The president and directors (of a bank) shall have the authority to employ supervisors, secretaries, tellers, accountants, bookkeepers and clerks to handle the operations of the bank; to establish salary levels for these employees; to act according to the interests of the bank; and to decide on the hiring, promotion and demotion of the aforementioned employees at meetings of the board of directors. ${ }^{4)}$

From 1879 on, a large number of private banks were established along the lines of non-banking companies. Most of them too attempted to follow the structure of the national banks, and in so doing encountered the same difficulties with regard to the role of all directors other than the president himself that other companies had. They required that directors shall have the authority to determine the routine rules of the bank, to set salaries for personnel, and to decide on hiring, promoting and demoting employees at their meetings.

The Tokyo Stock Exchange, Japan's first such institution, was established in 1878 as a joint-stock company. The provision within its articles of incorporation dealing with its directors reflects the ambiguity of the term torishimariyaku, as well as confusion regarding directors' duties and rights. It reads as follows:

The directors (of the exchange) shall be empowered as a body to select non-managerial personnel and to determine the responsibilities, rights and salaries of said personnel. They shall also mediate disputes between stockholders, manage the expenditure of funds, decide the general administration of the exchange, create operational plans for the exchange and present them to the president, answer questions from stockholders, and hold general meetings to solicit the opinions of the stockholders.

The Meiji Life Insurance Company was established in 1881. It was the first of its kind in Japan, and its founders were men with considerable knowledge of the West. Taizo Abe, the company's president, had in fact studied statistics in the United States. Yet in this case too, we see the same kind of ambiguity with regard to the status of the company's directors as observed above:

The directors are responsible for overall managment (in the com- 
pany) .... . They are empowered to set salaries for non-managerial personnel, to act in accordance with the best interests of the company, and, after due discussion, to decide on the hiring, promotion and demotion of employees.

The Kiyo Trading Company was established in Nagasaki in 1883. Its rules stress very clearly the function of the company's directors as representatives of its stockholders:

The directors represent the stockholders as a whole, and in this capacity they have the authority to oversee the company's finances and the performance of its employees. If the company is involved in impropriety, they are to appoint a new president after consulting with all the stockholders.

Joint-stock companies were set up in the modern industrial sector as well after about 1880 . The earliest, however, was the very large Cement Production Company (later renamed the Onoda Cement Company), established in Yamaguchi prefecture in 1879. This enterprise was started by a large number of investors, among whom were former feudal lords. Its rules concerning the directors of the company placed particular emphasis on their roles as representatives for the interests of stockholders:

The directors, like the president, are to be chosen by vote of the stockholders, and are to participate with the president in any decisions regarding the company. They are responsible to the stockholders for the operation of the company and for the supervision of its employees.

The most important manufacturing industry in this period was cotton spinning. The Enshu Cotton-Spinning Company, established in 1883, defined the duties and functions of its directors in terms very much like those noted above:

The directors are to visit the company from time to time to supervise the performance of the president. They are required to oversee constantly the operation of the company and the performance of its employees in accordance with the instructions they receive from the stockholders.

The Akagi Kohyo Company, established in Gunma prefecture in 1887 , stated in its articles of incorporation that the directors of the company "will normally have no responsibility for the operation of the firm."

Different provisions with regard to the role of directors began to be adopted at the end of the 1880s. Japan's first large-scale silk cloth 
manufacturing company, the Kyoto Textile Company (established in Kyoto in 1889) provided that its directors make practical decisions as to the management of the firm:

The directors are to meet at the company at least twice a month in order to make decisions on all important matters concerning the company. The president of the company is to act as chairman of these meetings. ${ }^{5)}$

As the aforementioned examples make clear, although the top management of joint-stock companies established in Japan in the 1870s and 1880s bore an outward similarity to the Western board of directors model, in practice the rights and duties of directors varied considerably from firm to firm, and the position itself was a rather ambiguous one. With the above examples, as well as others, in mind, the duties of a firm's directors during this period can be summarized roughly as follows: 1) to formulate rules with regard to the routine operation of the company and the duties of its employees; 2) to handle personnel matters for non-managerial employees; and 3) to determine salaries for all employees.

The records of companies which were operating during this period and whose boards of directors were restricted to the functions described above show that there was no real work for directors other than the president, aside from meeting once a month or at most once a week. Generally, therefore, directors were unsalaried; and salaries for those who did receive them were very low. Directors, of course, had their own sense of self-esteem, but they apparently considered their lack of remuneration proper enough, and were satisfied with their lot. There are no instances where directors requested financial compensation for their services, or, in the event they did receive salaries, higher ones.

As a result, in the 1880 s there was a natural inclination among those who had knowledge of business practices in the West to criticize the way directors and boards of directors functioned in Japan. In 1884, Ukichi Taguchi, the publisher of what was then Japan's most influential economic journal, the Tokyo Keizai Zasshi, argued that "directors have no authority at all, and their position is equivalent to being in retirement." With regard to bank directors, he offered the following observations:

These directors might as well be retired. They have no interest in business trends in general, or in the organizational aspects of their banks. The result is that the president handles everything himself; his power is unlimited, and this gives rise to many problems. $^{6)}$ 
Taguchi took up the problem again in 1887 , when, in an article titled "The Organization of Companies," he compared the position of directors in Japanese firms with that in the West, and argued that Japanese directors were irrelevant:

In Western firms, ultimate authority rests with the board of directors. These directors are themselves wealthy businessmen or the heads of commercial organizations; they have a good deal of experience in running businesses. They set up the companies of which they are directors in order to invest their wealth safely. In Japan, directors are chosen at stockholders' meetings, and they are usually stockholders who helped draft the company prospectus, clever speakers who helped the firm find investors, wealthy people with no talent, and the like. They are completely different from their counterparts in the West. They make business decisions in restaurants, where policy with regard to productivity increases and sales is handled in the midst of chitchat with geisha. ${ }^{7)}$

Under this kind of organizational structure, most people in directorial positions lacked a clear perception of their rights and responsibilities, and did not see themselves much differently from the rest of the firm's stockholders. Nor, to the extent that they lacked the necessary talent, did they attempt to improve their situation. Consequently, except for cases where the president of the company ran virtually every thing himself, the common if informal pattern was for those in actual managerial positions - the shihainin (manager) - to take responsibility for decisionmaking. These were men of talent and experience, and in new industries like insurance, railroads, manufacturing and mining, they were often young and knowledgeable in the ways of modern industry. It is important to note that, unlike a firm's directors, the authority and responsibilities of the shihainin were usually spelled out rather specifically in the company's articles of incorporation.

The Cement Production Company, for example, provided in its articles that

The manager is to function as the president's closest assistant. He is responsible for the quality of both raw material and output, for the condition of the machinery, and for the performance of the firm's employees. When the president is away, he is to act as his representative.

The Meiji Life Insurance Company provided that "the manager is directly responsible to the president for directing the operations of the 
company according to the president's wishes." Similarly, the Kiyo Trading Company provided that

The manager is to assist the president of the company. It is he who must supervise the daily operations of the firm, evaluate the firm's managerial policy, and direct the firm's employees.

The Kakugyo Trading Company, established in 1883, stated in its articles of incorporation that

The manager is responsible for the operation of the company in accordance with the instructions of the president. He must encourage the staff and see that production is carried out smoothly and efficiently.

Likewise, the Kurashiki Cotton Spinning Company, founded in 1888, provided that "the manager is responsible for the firm's purchases and sales, for the performance of its employees, and for the expansion of its operations." $"$ )

Included in the National Bank Ordinance was a provision that bank managers should "handle the various activities of the bank in accordance with directions received from the president and the board of directors." Although this put managers in a middle position, subordinate to the board of directors, in fact it was expected from the first that they would rank second in importance only to the president. Eiichi Shibusawa, who resigned from a high post in the Finance Ministry to become president of the First National Bank, exhorted and helped others set up national banks; in each case, when he asked to see documents pertaining to those in positions of responsibility, he made it clear that he wished to see those for the president and manager.

The position of managers being what it was, their salaries were second only to the president of the firm (see table 1). For example, at the First National Bank, the president received a monthly salary of 50 yen, while the manager received $40 \mathrm{yen}^{9}$ ); at the Fourth National Bank, the president's monthly salary was 28 yen, while the manager's was 24 yen. ${ }^{10}$ ) These were typical salaries for banks in large urban areas and in the country-side, respectively. The salaries managers received reflected the fact that, regardless of whether they received compensation or not, directors other than the president of a business enjoyed a position much lower than did the managerial staff. There was almost no ressistance on the part of members of boards of directors to the assignment of actual managerial responsibility to the management staff; nor, even though they may have expected high substantial financial reward for themselves, did 
Table 1 Manager of Principal Firms, 1868 - 1895

\begin{tabular}{|c|c|c|c|c|}
\hline Bank/Company & Manager & Period of Service & $\begin{array}{l}\text { Monthly } \\
\text { Salary }\end{array}$ & Later Position \\
\hline The First Bank & $\begin{array}{l}\text { Yūnosuke } \\
\text { Sasaki }\end{array}$ & $1881-1896$ & 40 & $\begin{array}{l}\text { President } \\
\text { (Tödori) }\end{array}$ \\
\hline The Fourth Bank & $\begin{array}{l}\text { Haruzō } \\
\text { Shirase }\end{array}$ & $1889-1896$ & $24-40$ & $\begin{array}{l}\text { Senior Executive } \\
\text { Director }\end{array}$ \\
\hline The Seventh Bank & $\begin{array}{l}\text { Katsuyoshi } \\
\text { Ōwaki }\end{array}$ & $1890-$ & & $\begin{array}{l}\text { President } \\
\text { (Tōodori) }\end{array}$ \\
\hline The Tenth Bank & $\begin{array}{l}\text { Sakutarō } \\
\text { Satake }\end{array}$ & $1877-1881$ & 20 & $\begin{array}{l}\text { President } \\
\text { (Tōdori) }\end{array}$ \\
\hline The 18th Bank & $\begin{array}{l}\text { Shōzaburō } \\
\text { Matsuda }\end{array}$ & $1894-1897$ & 25 & $\begin{array}{l}\text { President } \\
\text { (Tōdori) }\end{array}$ \\
\hline The 19th Bank & $\begin{array}{l}\text { Hikosuke } \\
\text { Nakayama }\end{array}$ & $1877-$ & 33 & $\begin{array}{l}\text { Vice President } \\
\text { (Fuku Tōdori) }\end{array}$ \\
\hline The 77th Bank & $\begin{array}{l}\text { Nobunari } \\
\text { Nakajima }\end{array}$ & $1878-1887$ & 20 & Director \\
\hline The 85th Bank & $\begin{array}{l}\text { Kashichi } \\
\text { Yamazaki }\end{array}$ & $1878-1892$ & 25 & $\begin{array}{l}\text { President } \\
\text { (Tōdori) }\end{array}$ \\
\hline $\begin{array}{l}\text { Yokohama } \\
\text { Specie Bank }\end{array}$ & $\begin{array}{l}\text { Mitsukage } \\
\text { Ono }\end{array}$ & $1879-1882$ & & $\begin{array}{l}\text { President } \\
\text { (Tōdori) }\end{array}$ \\
\hline $\begin{array}{l}\text { Tokyo Electric } \\
\text { Co. }\end{array}$ & $\begin{array}{l}\text { Ichisuke } \\
\text { Fujioka }\end{array}$ & $1886-1898$ & 50 & \\
\hline $\begin{array}{l}\text { Osaka Electric } \\
\text { Co. }\end{array}$ & $\begin{array}{l}\text { Nobunari } \\
\text { Kashima }\end{array}$ & $1889-1894$ & $30-70$ & $\begin{array}{l}\text { Executive } \\
\text { Director }\end{array}$ \\
\hline $\begin{array}{l}\text { Tokyo Rope } \\
\text { Mfg. Co. }\end{array}$ & $\begin{array}{l}\text { Masakuni } \\
\text { Yamada }\end{array}$ & $1887-1898$ & 50 & $\begin{array}{l}\text { Senior Executive } \\
\text { Director }\end{array}$ \\
\hline $\begin{array}{l}\text { Oji Paper } \\
\text { Mfg. Co. }\end{array}$ & $\begin{array}{l}\text { Keizō } \\
\text { Tani }\end{array}$ & $1874-1893$ & 150 & $\begin{array}{l}\text { Senior Executive } \\
\text { Director }\end{array}$ \\
\hline $\begin{array}{l}\text { Nippon Flour } \\
\text { Mill Co. }\end{array}$ & $\begin{array}{l}\text { Kojirō } \\
\text { Takagi }\end{array}$ & $1896-1907$ & 30 & Director \\
\hline $\begin{array}{l}\text { Tokyo Marine } \\
\text { Insurance Co. }\end{array}$ & $\begin{array}{l}\text { Katsunori } \\
\text { Masuda }\end{array}$ & $1879-1897$ & 100 & Auditor \\
\hline $\begin{array}{l}\text { Meiji Life } \\
\text { Insurance Co. }\end{array}$ & $\begin{array}{l}\text { Kiyohisa } \\
\text { Mozume }\end{array}$ & $1881-1910$ & 50 & Director \\
\hline $\begin{array}{l}\text { Osaka Spinning } \\
\text { Co. }\end{array}$ & $\begin{array}{l}\text { Takeo } \\
\text { Yamanobe }\end{array}$ & $1883-1895$ & 80 & President \\
\hline $\begin{array}{l}\text { Hirano Spinning } \\
\text { Co. }\end{array}$ & $\begin{array}{l}\text { Kyōzō } \\
\text { Kikuchi }\end{array}$ & $1888-1896$ & & \\
\hline $\begin{array}{l}\text { Amagasaki } \\
\text { Spinning Co }\end{array}$ & $\begin{array}{l}\text { Kyōzō } \\
\text { Kikuchi }\end{array}$ & $1889-1893$ & $20-70$ & President \\
\hline $\begin{array}{l}\text { Settsu Spinning } \\
\text { Co. }\end{array}$ & $\begin{array}{l}\text { Kyōzō } \\
\text { Kikuchi }\end{array}$ & $1890-1897$ & $50-60$ & President \\
\hline Tokyo Gas Co. & $\begin{array}{l}\text { Motoaki } \\
\text { Sasase }\end{array}$ & $1885-1898$ & & Director \\
\hline $\begin{array}{l}\text { Kyoto Textile } \\
\text { Co. }\end{array}$ & $\begin{array}{l}\text { Shinzaburō } \\
\text { Tsujikawa }\end{array}$ & $1891-1893$ & 100 & $\begin{array}{l}\text { Senior Executive } \\
\text { Director }\end{array}$ \\
\hline
\end{tabular}


Note 1) List includes head engineers (Gishichō)

2) Salary Figures refer to salaries upon assumption of post (or immediately thereafter). Most were subsequently increased.

3) The First through the Eighty-fifth Banks were national banks until 1983.

Source: Company histories, biographies and annual reports. For details, contact the author.

directors complain about the salaries received by their firm's manager. Part of the reason for this attitude was the fact that in traditional merchant houses in the past, it had become common practice for the family owning the business to give managerial power and responsibility to managers (banto) chosen from outside the family.

During this period, then, the role of the manager of a business was much more important than that of the members of the board of directors. In fact, the manager often ran the business himself, and in some cases this de facto position became an official one as well. As the information for representative firms for this period in Table 1 makes clear, managers ultimately advanced to top-level positions within their respective firms. Whatever his actual authority and responsibility, however, in other ways the manager enjoyed a status considerably lower than the members of his firm's board of directors. This reflected the persistence of traditional social values: the pre-Meiji manager of a business was expected to oversee the operation, but his status was clearly subordinate and he was expected to show absolute loyalty to the owner. The result of this situation, almost inevitably, was a good deal of structural instability at the top of Japanese businesses during the early Meiji years, and a rather awkward position for the managers who, more often than not, wielded genuine authority.

\section{The Emergence of the Senior Executive Director}

Although, as we have seen, Japanese firms in the first decades of the Meiji period did attempt to model their managerial structure on what they found in the West, the imitation was never a complete one, and the resulting structure was unstable. Modern industries clearly required a better structure under which to operate than had been devised thus far. In the latter half of the 1880s the Meiji government, which had adopted as national policy the promotion of new industries and overall increases in productivity, became concerned about the instability and structural weaknesses apparent in Japanese business management. In addition, instances where directors embezzled company funds were becoming increasingly common, and the government began to appreciate the need for legal prohibitions against action of this sort. The govern- 
ment therefore hastened to prepare civil and commercial codes at the same time it was drawing up the Meiji constitution, and the codes were issued in April 1890. Because of difficulties arising from differences between the new code and traditional commercial practice, enforcement of the commercial code was postponed. But so apparent was the need for legal provisions regarding business organizations that the corporate law section of the commercial code was put into effect in July 1893, and with this, legal standards were established for business management. The new law affirmed the authority of directors of joint-stock companies as official representatives of the firm, and officially recognized their administrative and decision-making power; it also made it clear that they were responsible legally for the management of their enterprise. The law did not specifically provide a legal basis for the structure of a board of directors, but did recognize its status as a company's highest permanent decision-making body.

The enactment of the corporate law section of the commercial code was a significant step, but it also introduced a new problem. The framers of the law, having observed how directors of Japanese firms were usually functioning, did not necessarily believe that the law should accord all directors equal status in the management of their business. Article 185 of the law, as a result, contained a provision allowing for the selection, from the board of directors, of a senior executive director to oversee a firm's operation. The effect of this article was to provide legal basis for an executive managerial position in addition to that of president. The term used in the article, senmu torishimariyaku, clearly implied a professional, full-time position. But this senior executive director was to be chosen by and from the board of directors, who thereby authorized him to act on their behalf; and from a legal standpoint his responsibilities were the same as those of the other directors. The difficulties arising from this part of the law were remedied in a new commercial code, issued in April 1899 and put into effect two months later, which left it up to individual firms to define the responsibilities, and determine the selection, of the senior executive director in their own bylaws.

The Sino-Japanese War of 1894-1895 was followed by the growth of preexisting industries and the establishment of new firms in the areas of rail transport, mining, and light industry. Such companies devised managerial structures (or, in the case of already established firms, revised their structures) in accordance with the new commercial code. In the process, most of the larger companies established the post of senior executive director ${ }^{11}$, and invested the position with responsibilities necessary to the proper functioning of the firm - this despite the fact 
that the new commercial code did not actually require the creation of such a post. The senior executive director came to enjoy a position of responsibility second to the president of the firm. In some instances, he functioned in lieu of the president when, there being no major stockholders with the necessary qualifications, that post was left vacant.

While this organizational change was being implemented in the private sector, the Meiji government was itself trying to encourage the introduction of a board of directors structure more like that found in the West. The most enthusiastic supporter within the government of this attempt was Prime Minister Hirobumi Ito, who took it upon himself to persuade the Nihon Yusen Kaisha (N.Y.K.), one of Japan's largest modern industrial firms and one whose growth had typified that of many Japanese businesses, to adopt a managerial structure closer to the Western model. At Ito's urging, in 1893 the company reorganized its board of directors, which as a consequence was composed of four managing directors from within the firm, as well as four representative businessmen and a rear admirals, all of whom functioned as outside directors. ${ }^{12)}$ The new structure ultimately collapsed, however, as the outside directors one by one resigned and the four inside directors were replaced by two senior executive directors.

In contrast to this, there was, among large industrial firms, a very rapid development of a managerial organization consisting of the president, the senior executive director, and the members of other directors (usually major stockholders). This was a rather more simplified structure than Ito had envisioned, but it was sufficient for most firms at the time: the supply of managerial talent for modern industries was, after all, still small; in addition, most firms were as yet relatively small, and their operations relatively simple. In the majority of cases, the services of the senior executive director were sufficient to ensure a firm's smooth operation.

The commercial code had given legal recognition to three forms of business organization: the kabushiki kaisha (joint-stock company), the goshi kaisha (limited partnership), and the gomei kaisha (unlimited partnership). Apart from the main businesses of the zaibatsu, the last two types of organization were limited mostly to very small-scale operations; the vast majority of Japan's larger companies were joint-stock companies. Table 2 shows the managerial structure of 567 banking and non-banking businesses with capital assets of 10,000 yen or more as of 1903. Of the 388 non-banking firms, 141 had managerial structures consisting of a president (or, in a few cases, a chairman of the board) and other directors; yet by this time fully 152 companies had a structure composed of a president (or, in some cases, none at all), a senior executive 
Table 2 Organization of Top Management (1903)

\begin{tabular}{|c|c|c|c|c|c|}
\hline \multirow[b]{2}{*}{ Organizational Type } & \multicolumn{2}{|c|}{ Tokyo } & \multicolumn{2}{|c|}{ Osaka } & \multirow[b]{2}{*}{ Total } \\
\hline & Non-Banking & Banking & Non-Banking & Banking & \\
\hline $\begin{array}{l}\text { President, } \\
\text { other Directors }\end{array}$ & 80 & 66 & 61 & 24 & 231 \\
\hline $\begin{array}{l}\text { President, Vice President } \\
\text { other Directors }\end{array}$ & 0 & 9 & 0 & 0 & 9 \\
\hline $\begin{array}{l}\text { President, Senior } \\
\text { Executive Director, } \\
\text { other Directors }\end{array}$ & 26 & 6 & 6 & 4 & 42 \\
\hline $\begin{array}{l}\text { President, Executive } \\
\text { Director, other Directors }\end{array}$ & 10 & 10 & 22 & 8 & 50 \\
\hline $\begin{array}{l}\text { Senior Executive } \\
\text { Director, other Directors }\end{array}$ & 66 & 23 & 22 & 4 & 115 \\
\hline $\begin{array}{l}\text { Senior Executive } \\
\text { President, other Directors }\end{array}$ & 12 & 0 & 4 & 1 & 17 \\
\hline Directors & 68 & 24 & 11 & 0 & 103 \\
\hline
\end{tabular}

Source: Shōgyō Kōshinjo, Nihon zenkoku shokaisha yakuin roku (Japanese Directory of Company Directors) (1903).

Note 1) Figures are for firms with capital assets of the least 10,000 yen.

(or managing) director, and other directors. Only 79 had neither a president nor a senior executive director. Among banking institutions, whose operations tended to be more uniform and to represent less of a departure from traditional business practices than the new industries, the predominant managerial structure continued to consist of a president (usually a major stockholder) and other directors. Even here, however, there were 55 cases in which the position of senior executive director had been instituted. Of equal importance, in both banking and other types of business, is the fact that the structure composed of president, senior executive director and other directors tended to be the norm among firms with substantial capital assets. Clearly this kind of organization had gained considerable favor over a very short period of time.

In the majority of cases where this organizational structure was adopted, those chosen to be senior executive directors were either the chief engineers (gishicho) or the general managers (shihainin) of their firms. Most of these men had had formal academic training in their field or had lived overseas, and had considerable managerial ability for the modern enterprises of which they were part. But because there were, at this point, so few such talented individuals, firms ran the risk of losing them to competitors if they were not promoted above the middle management level. Competition among firms for talented personnel also ef- 
fectively eliminated any opposition from a firm's board of directors to the promotion of these skilled people, despite the fact that the directors had always had a conspicuously higher status in the firm than those whose positions were being advanced. Newly-established companies actively engaged in efforts to woo talented personnel from firms in the same industry, and also tried to draw career professionals - government officials, lawyers, and the like - into their ranks.

The first senior executive directors were not a significant source of capital for the firms in which they were employed, and there were therefore instances where their stock holdings did not meet the minimum requirements for the position to which they were appointed. In such cases, firms simply altered their articles of incorporation to reduce the required stock holdings for senior executive directors, or made them nominal stockholders.

In practice, a senior executive director often functioned as the chief executive of his firm, with the powers and responsibilities appropriate to the position, and in fact controlled the firm's entire operation. The president of a firm had to be a major investor as well as one who enjoyed considerable social prestige; but if a firm had a talented senior executive director, the president was often a figurehead. As a result, the senior executive director was able to receive a salary far above what he had gotten prior to his promotion, as well as substantial bonuses. From the early 1900s, it was common for a firm's board of directors to assign ten to twenty percent of the firm's annual profits to "directors' bonuses"; and the senior executive director often got as much as half of this. Hikojiro Nakamigawa, the senior executive director of the Mitsui Bank, asked the Mitsui family for a bonus of ten percent of their bank's profits, and was known as "Asia's highest salaried executive."13) Toyoji Wada, senior executive director of the Fuji Cotton-Spinning Company, likewise received ten percent of his firm's profits - in this case, a bonus of 300,000 yen - in 1905; his bonus was twice that of all the other members of the board of directors, including the president, combined. ${ }^{14)}$

Senior executive directors commonly ủsed their substantial incomes to increase, to one degree or another, their stock holdings in the firm, and sought thereby to consolidate their position - a task they achieved, at least in Japan's larger firms, by about 1910. Senior executive directors made up a large proportion of the real leadership in many Japanese businesses during the first decades of the twentieth century. Table 3 shows typical examples of such individuals, as well as their period of employment. Most of them were celebrated, then as now, as outstanding business leaders. The captains of industry in Japan were not, like in the West, 


Name
Heizaburō Okawa
Takashi Masuda
Hikojirō Nakamigawa
Sumisaburō Uemura
Takuma Dan
Raita Fujiyama
Toyokichi Sakai
Seisyū Iwashita
Eiji Asabuki
Kunihiko Iwatare
Toyoji Wada
Umeshirō Suzuki
Senjirō Watanabe
Osuke Hibi
Hanji Sōma
Ichizō Kobayashi
Genjirō Yonei
Sanji Mutō
Seiichi Umemura
Ginjirō Fujiwara
Seijirō Miyajima
Hachisaburō Hirao
Kenkichi Kagami

Firm
Oji Paper Mfg. Co.
Mitsui \& Co.
Mitsui Bank
Sapporo Brewery Co.
Mitsui Mining Co.
Oji Paper Mfg. Col
Nippon Flour Mill Co.
Kitahama Bank
Mitsui Drapery Co.
Nippon Electric Co.
Fuji Spinning Co.
Oji Paper Mfg. Co.
Mitsui \& Co.
Mitsukoshi Ltd.
Meiji Sugar Mfg. Co.
Mino-o Arima (Hankyu) Electric
Railway Ltd.
Kirin Brewery Co.
Kanegafuchi Spinning Co.
Ishikawajima Shipbuilding Co.
Oji Paper Mfg. Co.
Nisshin Spinning Co.
Tokyo Marine Insurance Co.
Tokyo Marine Insurance Co.

Period of Service

$1893-1898$

$1894-1903$

$1894-1904$

$1894-1906$

$1894-1909$

$1896-1902$

$1896-1912$

$1897-1900$

$1898-1902$

$1899-1926$

$1901-1916$

$1902-1909$

$1903-1916$

$1904-1913$

$1906-1915$

$1907-1910$

$1916-1927$

$1907-1919$

$1908-1921$

$1909-1912$

$1911-1920$

$1914-1919$

$1917-1925$

$1917-1925$

Source: Shōgyo Kōshinjo. Nihon Zenkoku Shokaisha Yakuin Roku (1900 - 1927)

industrial capitalists, but rather these salaried career executives.

The early twentieth century also saw the development of a new managerial position, that of senior executive president. This position was, in fact, assumed by senior executive directors in cases where the post of president was vacant, or where the senior executive director had accumulated enough stock in the company to advance further. Those who ausumed this position included Renpei Kondo, who held the post between 1895 and 1920 in the Nihon Yusen Kaisha (N.Y.K.); Michinari Suenobu, who held it between 1902 and 1906 in the Tokyo Marine Insurance Company; Taizo Abe of the Meiji Life Insurance Company, who served between 1895 and 1906; and Seishu Iwashita, who held the position in Osaka's Kitahama Bank between 1900 and 1914. In the first three cases, it is worth nothing, the companies concerned were the largest 
of their kind in Japan.

\section{The Development of Hierarchical Management}

As we have seen, the senior executive director assumed a preeminent position in Japanese business from the end of the nineteenth century. At the same time, though, the fact that the commercial code had specifically delineated the powers and responsibilities of the other members of a firm's board of directors made it increasingly imperative that the ambiguities inherent in their actual functioning be resolved. Two trends can be observed concerning these directors in the early twentieth century. The first was a decreasing tendency to appoint directors solely on the basis of their holdings in the firm, or on their participation in the establishment of the enterprise. This trend reflected the wishes of the government and the urging of Ukichi Taguchi and other intellectuals. Although businesses over time vastly increased their size and the scope of their activities, the number of directors in a firm rarely if ever went up; in fact, as directors' responsibilities became more onerous, their numbers sometimes fell. At the same time, however, a system of financial compensation for directors became increasingly common, as did the practice of awarding large bonuses at the end of the accounting period.

The second trend was for directors to be chosen, like the senior executive director, on the basis of their experience, ability and sense of responsibility, and for these directors to come increasingly from the ranks of the firm's full-time professional management rather than from investors who participated in the firm's activities on at best a part-time basis. Investors in a firm continued to enjoy substantial power and prestige, and it took time to build up a qualified managerial staff from which to select new directors. The shift in power was not, therefore, dramatic or sudden, but very gradual; nevertheless, the trend was clear. ${ }^{15}$ )

Japan's stronger international position as a result of the Russo-Japanese War (1904-1905) accelerated the pace of the country's industrialization. Light industries began exporting their wares to other Asian countries, and the number of private firms engaged in heavy industry began to rise. Table 4 shows the organizational structure of the 1,100 firms with capital assets of at least 100,000 yen in the major urban areas of Tokyo, Osaka, Kanagawa (Yokohama) and Hyogo (Kobe) as of 1912. At this point, fully 306 companies had a managerial structure composed of a president, senior executive (or executive) director, and directors. This is a substantial increase over previous years; and, when the number of firms (most of them rather small-scale) with only a board of directors is excluded, it is apparent that this kind of managerial organization was dominant in 


\section{Organizational Type}

1. President - Senior Executive Director Executive Director other Directors

2. President - Senior Executive Directors other Directors

3. President - Executive Directors - other Directors

4. Senior Executive Director - Executive

Director - other

Directors

5. Senior Executive (or Executive) Director other Directors

6. President - other Directors

7. President - Vice President - other

\section{Directors}

8. President - Vice President - Senior Executive Director other Directors

Source: Shōgyō Kōshinjo, Nihon zenkoku shokaisha yakuin roku (1913).

Note 1) In the third and fifth organizational types, a senior executive president sometimes took the place of the president. 2) Figurses are for firms with capital assets of at least 100,000 yen.
Kanagawa

Hyogo

Non-Banking Banking

79

13

2

10

20

2

7

5

8

81

45

53

14

11

14

4

2

0

3

1

3

0

0

0

1
0

anking

0

3

0


Japanese industry by this time. In addition, there were 19 firms with a structure composed of a president, senior executive director, executive director, and directors. This kind of organization would become increasingly typical of large firms in Japan, and, if the firms whose structure was the same as this save for the absence of the post of president are included, there were already 33 such companies. ${ }^{16)}$

In the latter half of the 1910s, as the scale of businesses in Japan increased and the responsibilities of their managerial staffs widened, it frequently became necessary for other professional, full-time directors to assume some of the duties previously handled by the senior executive director, to assist the latter in his work, or to take on new duties which resulted from the firm's expansion. It is important to note that in almost every instance where this was done, there was never more than one senior executive director in the firm. Rather, a vertical structure was created in which one or two executive directors functioned below the senior executive director and the president. In other words, even as the managerial functions within a firm became more complex, there was less a tendency for responsibility to be divided among the members of the board of directors (something which, as we have seen, the government had urged) than for a hierarchical structure to develop quite apart from these directors.

Let us now consider this new hierarchical structure as it existed in 1921. Table 5 shows the organizational patterns of 1,797 Tokyo-based joint-stock companies with capital assets of 300,000 yen or more. The number of firms with a managerial structure consisting of a president, senior executive director and directors had increased to 179; but there were also 90 firms (including those with vice-presidents) which had the additional position of executive director. The statistics clearly reflect the development of the post of executive director, and with it a hierarchical structure of management.

The number of executive directors a firm might employ at one time also began to rise, and the responsibilities of these directors broadened. Some of the major firms began to make use of two or three executive directors; a few began to employ such directors specifically for sales and, separately, for production. In addition, some firms began to appoint managing directors, men who were not, by and large, important stockholders in the firm, and who did not have the age or prestige of the senior executive and executive directors. These managing directors in time became a distinct part of the hierarchical structure, separate from the executive directors, and were known as junior (hira) executive directors. ${ }^{17)}$ Most of them had risen from within the firm's middle manage- 
Table 5 Organization of Top Management (1921)

Organization Type

Number of Firms

President - Senior Executive Directors - other Directors

179

President - Vice President - other Directors

5

President - Vice President - Senior Executive lor

Executive) Directors - other Directors

President - Vice President - Senior Executive Director -

1

Executive Directors - other Directors

President - Senior Executive Director - Executive Director 72

- other Directors

President - Executive Director - other Directors 176

$\begin{array}{ll}\text { President - Board of Directors } & 159\end{array}$

Senior Executive (or Executive) Director - other Directors $\quad 85$

Senior Executive Director - Executive Director - other 23

Directors

Directors

1,071

Other

Directors

Senior Executive Director - Executive Director - other

Directors

Directors

Source: Shō gyō Kō shinjo, Nihon zenkoku shokaisha yakuin roku (1921).

Note 1) Figures are for Tokyo-based firms with capital assets of at least 300,000 yen.

ment, and therefore had considerable experience in the business. This new management structure - i.e., president, senior executive director, executive director(s) and junior executive director(s) - began to be adopted by larger companies in the $1920 \mathrm{~s}$. Changes in the managerial structure of Japanese firms from the 1920s on are beyond the scope of this paper; but it should be noted that work has been published regarding the rise to directorial positions of individuals from within a firm's middle management. ${ }^{18)}$

The introduction of the position of managing director, and the development of the hierarchical structure of management of which it was a part, reflected the lack of development of a Western-style board of directors structure as a practical decision-making body. There was, in addition, not much possibility for the development in Japan of an executive committee style of management. Rather, the functions performed in the West by a board of directors were appropriated by a hierarchical organiza- 
tion of executive directors who, in time, themselves became the board of directors. The result of this process was to give the board of directors an inclusive, in tra-firm character.

\section{Epilogue}

During the half century of rapid development that followed the Meiji Restoration, large firms which had organized as joint-stock companies experienced a remarkable period of growth. Just as Japan's industrialization was itself, in a sense, a borrowed phenomenon, so too was the structure of the joint-stock company a borrowed idea; yet, as established in Japan, these companies differed substantially from their Western counterparts. The focus of this paper has been on the managerial structure of these firms, and on how and when this structure developed into a hierarchical group of directors who both owned and managed their enterprise. The resulting structure was very different from the original Western model. Although we have only considered developments between 1870 and 1920, in fact this unique managerial structure has, in the postwar period and even during the Second World War, continued to evolve and to become the common pattern. To a certain degree, this structure can be viewed as a result of a lack of sufficient capital and managerial resources, which worked to retard the process of industrialization, and of conscious efforts to fill managerial positions with university graduates and to train them within the firm. This process of managerial selection and training is beyond the scope of the present essay, but much work is being done in this area by students of Japanese business history.

Note: this article is, in the main, an English translation of an earlier work by the author, "Meiji jidai ni okeru juyaku soshiki no keisei," Keiei shigaku vol. 14 no. 1.

\section{Notes}

1) Increasingly common in large Japanese firms since about 1960 has been the jomukai (often referred to as "executive committee"). Junior executive directors do not participate in meetings of this committee, thus making it considerably different from its predecessors.

2) A good deal of research has been done on these companies. See, for example, Wataro Kanno, Nihon kaisha kigyo hassei shi no kenkyu (Tokyo, 1931).

3) Meiji Zaisei Shi Hensankai, ed., Meiji zaisei shi (The History of Meiji 
Public Finance), vol. 13 (Tokyo, 1937), p. 91.

4) Ibid., p. 183.

5) Rules pertaining to boards of directors are taken from the articles of incorporation of the firms cited. For specific sources, see Tsunehiko Yui, "Meiji jidai ni okeru juyaku soshiki no keisei," Keiei shigaku (Japan Business History Review) vol. 14 no. 1.

6) Taguchi Ukichi zenshu, vol. 4 (Tokyo, 1928), pp. 191-193.

7) Tokyo keizai zasshi 350 (January 1887) : 20-21.

8) See Yui, "Meiji jidai ni okeru juyaku soshiki no keisei" for information on the original documents containing the articles of confederation quoted here.

9) Daiichi Ginko 80 Nen Shi Hensankai, ed., Daiichi ginko shi (The History of the Daiichi Bank) (Tokyo, 1957), p. 131.

10) Daishi Ginko Kikakubu, ed., Daishi ginko hyakunen shi (One Hundred Years of the Daishi Bank) (Niigata, 1974), p. 57. At the time, one yen was worth slightly less than one American dollar.

11) On occasion during this period, the senior executive director was called jomu (rather than senmu) torishimariyaku.

12) Kazuo Suehiro, Kondo Renpei oyobi iko (The Biography of Renpei Kondo) (Tokyo, 1926), pp. 246-47.

13) The exact amount of Nakamigawa's bonus is not known. His salary upon taking his post was 250 yen per month - not a very large amount. But the bank's records for that year (1893) indicate that 68,000 yen was appropriated to the bank's directors as bonuses, and half of that is thought to have gone to Nakamigawa. See "Mitsui ginko shokuinbo 1893 nen 1 gatsu" and "Mitsui ginko eigyo hokokusho" (December 1893).

14) Tsunehiko Yui, "Nihon ni okeru juyaku soshiki no hensen," Keiei ronshu vol. 24 no. 3-4 (March 1977) : 39-40.

15) In Nihon keiei shi (Japanese Business History) (Tokyo, 1981), Hidemasa Morikawa discusses the position of "salaried executive directors" in 1905 (for banks and railroad companies with real capital assets of at least 2,000,000 yen, and for other firms with assets of at least 1,000,000 yen) and 1913 (for banks, electric power companies and mining companies with assets of at least 3,000,000 yen, and for other firms with assets of at least $1,500,000$ yen). Of 75 major firms examined for 1905, 22 had such directors; of the 115 firms examined for 1913, 39 had such directors. Six firms had two people in this position. See especially p. 89.

16) The terms senmu torishimariyaku (senior executive director) and jomu torishimariyaku (executive director) are very close in meaning, 
and were sometimes used interchangeably (see note 11). The latter term, however, was generally used to indicate a more direct managerial position.

17) The appellation hira was an informal one, and was not used officially.

18) Hidemasa Morikawa, "The Significance and Process of Development of Middle Management in Japanese Business," in Organization and Management 1900-1930 [Proceedings of the Japan-Germany Conference on Business History], ed. Keiichiro Nakagawa and Tsunehiko Yui (Tokyo, 1981). See especially pp. 135-37. 